\title{
Candidatus Rickettsia colombianensi in ticks from reptiles in Córdoba, Colombia
}

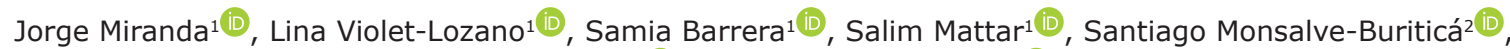 \\ Juan Rodas ${ }^{3}$ (i) and Verónica Contreras ${ }^{1}$ (i) \\ 1. University of Córdoba, Institute of Tropical Biology Research, Córdoba, Colombia; 2. Corporación Universitaria \\ Lasallista, Colombia; 3. University of Antioquia, Colombia, Colombia. \\ Corresponding author: Jorge Miranda, e-mail: jorgemire@hotmail.com \\ Co-authors: LV: linaviolet14@gmail.com, SB: samy21_biol@hotmail.com, SM: mattarsalim@hotmail.com, \\ SaM: santiagomonsalve@gmail.com, JR: jdavid.rodas@udea.edu.co, VC: verocontreras.helios@gmail.com \\ Received: 11-02-2020, Accepted: 09-07-2020, Published online: 03-09-2020
}

doi: www.doi.org/10.14202/vetworld.2020.1764-1770 How to cite this article: Miranda J, Violet-Lozano L, Barrera S, Mattar S, Monsalve-Buriticá S, Rodas J, Contreras V (2020) Candidatus Rickettsia colombianensi in ticks from reptiles in Córdoba, Colombia, Veterinary World, 13(9): 1764-1770.

\begin{abstract}
Background and Aim: Wildlife animals are reservoirs of a large number of microorganisms pathogenic to humans, and ticks could be responsible for the transmission of these pathogens. Rickettsia spp. are the most prevalent pathogens found in ticks. This study was conducted to detect Rickettsia spp. in ticks collected from free-living and illegally trafficked reptiles from the Department of Córdoba, Colombia.
\end{abstract}

Materials and Methods: During the period from October 2011 to July 2014, ticks belonging to the family Ixodidae were collected, preserved in 96\% ethanol, identified using taxonomic keys, and pooled (between 1 and 14 ticks) according to sex, stage, host, and collected place for subsequent DNA extraction. Rickettsia detection was performed using real-time polymerase chain reaction (RT-PCR), followed by conventional PCR to amplify a larger fragment of the gltA and $16 S$ rRNA genes. The amplicons were sequenced using the Sanger method, and the nucleotide sequences were subjected to BLAST analysis to identify homologous sequences in GenBank, after which phylogenetic analysis was performed using the MEGA X software.

Results: In total, 21 specimens of nine species of reptiles were sampled, from which 805 Amblyomma dissimile ticks were collected, but only 180 ticks were selected to create 34 groups. The DNA of Rickettsia spp. was detected in 30/34 (88\%) groups. The sequences of the gene gltA and $16 \mathrm{~S} r R N A$ revealed a $100 \%$ identity with Candidatus Rickettsia colombianensi (GenBank: KF905456 and GenBank: KF691750).

Conclusion: $A$. dissimile was the only tick found in all the sampled reptiles. The presence of Candidatus Rickettsia colombianensi in reptile ticks could represent a public health problem due to the risk of transmission to humans and the introduction of microorganisms to other geographical areas.

Keywords: arthropod vectors, reptile trade, tick-borne diseases, wild animals.

\section{Introduction}

Wildlife animals are reservoirs of a large number of microorganisms that are pathogenic to humans. Approximately $61 \%$ of human diseases are known to have a zoonotic origin, and $75 \%$ of emerging zoonoses worldwide are associated with wild animals [1]. Vertebrate mammals and animals belonging to other taxa, including reptiles and amphibians, serve as hosts for blood-sucking ectoparasites such as ticks [2]. Ticks are the second vector, after mosquitoes, responsible for the significant transmission of vector-borne diseases [3], and the vertebrate hosts can be infected by various protozoa, bacteria, and viruses, which cause $17 \%$ of infectious diseases worldwide [3-5].

Copyright: Miranda, et al. Open Access. This article is distributed under the terms of the Creative Commons Attribution 4.0 International License (http://creativecommons.org/licenses/ by/4.0/), which permits unrestricted use, distribution, and reproduction in any medium, provided you give appropriate credit to the original author(s) and the source, provide a link to the Creative Commons license, and indicate if changes were made. The Creative Commons Public Domain Dedication waiver (http:// creativecommons.org/publicdomain/zero/1.0/) applies to the data made available in this article, unless otherwise stated.
An increasing number of studies suggest that reptiles are competent hosts of microorganisms such as Rickettsia spp., Borrelia spp., and Ehrlichia spp. [6-8]. Colombia, with abundant biodiversity, has high rates of illegal trade in wild animals, covering both domestic and international markets [9]. Animals that are trafficked illegally often carry ticks with them, thereby representing a route of dispersal and introduction of tick species and pathogens to new geographical areas [10-12].

The bacteria belonging to the genus Rickettsia are a type of Alphaproteobacteria, obligate intracellular, possessing Gram-negative characteristics but are best visualized by Gimenez staining [13]. Rickettsia spp. comprise one of the most common microorganisms detected in reptile ticks [6], and to date, 23 Rickettsia species and several other Candidatus are known to be associated with at least 18 tick species found in 42 species of amphibian and reptile hosts reported in 36 countries [8]. Rickettsia has been found in the tissues of lizards, which could represent a model for studies on the epidemiology and pathogenesis $[6,14]$. 
Candidatus Rickettsia colombianensi has been identified in reptiles from Mexico, Honduras, Colombia, and Brazil, and it is probable that its distribution is related to the presence of Amblyomma dissimile, which ranges from the north of Mexico to the Southern Cone of America [8]. Some researchers consider that Candidatus Rickettsia colombianensi has an endosymbiont relationship with reptile ticks [8]. However, it has also been reported that it has a remarkable cytopathic effect on Vero cells [15], and its gene sequences relate it among the Rickettsia spotted fever group, which causes diseases in humans $[15,16]$.

Regarding the potential role of reptiles as reservoirs, there is a scarcity of information, and the issue requires further evaluation [14]. Therefore, the aim of this study was to detect Rickettsia spp. in ticks collected from free-living and illegally trafficked reptiles, which were seized by authorities in the Department of Córdoba (Colombia).

\section{Materials and Methods}

\section{Ethical approval}

The Ethics Committee of the Institute of Tropical Biology Research at the University of Córdoba approved the ethics protocol to obtain the samples of ticks from animals. The study incorporated management procedures to preserve the integrity of the animals according to the resolution 8430 of the Ministry of Health of Colombia.

\section{Type of study and geographical area}

From October 2011 to July 2014, we carried out a descriptive study in some areas of Department of Córdoba. The ticks samples were taken for convenience due to the availability of the reptiles specimens coming from seizures of illegal traffic and collections from biological studies. The region of the study is a highly fragmented tropical dry forest, with vegetation modified by human agricultural activities such as livestock and corn, rice, vegetables, citrus, and other tropical fruits. The average annual temperature is $29^{\circ} \mathrm{C}$, reaching $38.5^{\circ} \mathrm{C}$ in the dry season, and $27^{\circ} \mathrm{C}$ in the rainy season.

Ticks from illegally trade reptiles were collected by the environmental authority of Colombia in charge of wildlife (CAV-CVS) located in the city of Montería, DepartmentofCórdoba $\left(8^{\circ} 48^{\prime} 04.0^{\prime \prime} \mathrm{N}-75^{\circ} 50^{\prime} 75,9^{\prime \prime} \mathrm{W}\right)$. Besides, free-living reptile ticks collected in the municipality of Montería, at the University of Córdoba (08 45'15.71" N-75'51'28.01" W) and "Las Palomas" (08³0'37.1" N-7606'12.9” W); "El Zapal," municipality of Cereté $\left(8^{\circ} 55^{\prime} 40.80^{\prime}\right.$ " N-75 $45^{\prime} 40.93^{\prime}$ ' W), and "Paja Vieja," municipality of Lorica $\left(09^{\circ} 03\right.$ '50.7" N-75 55'34.4”'W) (Figure-1).

\section{Tick collection sites and taxonomic identification}

Ticks belonging the family Ixodidae were collected in all stages directly from individuals of the species Boa constrictor (common boa), Iguana iguana (green iguana), Kinosternon scorpioides (scorpion mud turtle), Bothrops asper (fer-de-lance viper), Erythrolamprus melanotus (Shaw's dark ground snake), Epicrates maurus (rainbow boa), Thamnodynastes gambotensis (snake), Imantodes cenchoa (blunt-headed tree Snake), and Trachemys callirostris (the Colombian slider turtle). The ticks collected from the reptiles were preserved in $96 \%$ ethanol and then transported to the Institute of Tropical Biology Research of the University of Córdoba. The identification of ticks was performed using the dichotomous taxonomic keys described by Barros-Battesti $[17,18]$. Ticks were grouped according to host, sex, stage, and geographic area, comprising 1-14 adults, 4-9 nymphs, and 1-7 larvae.

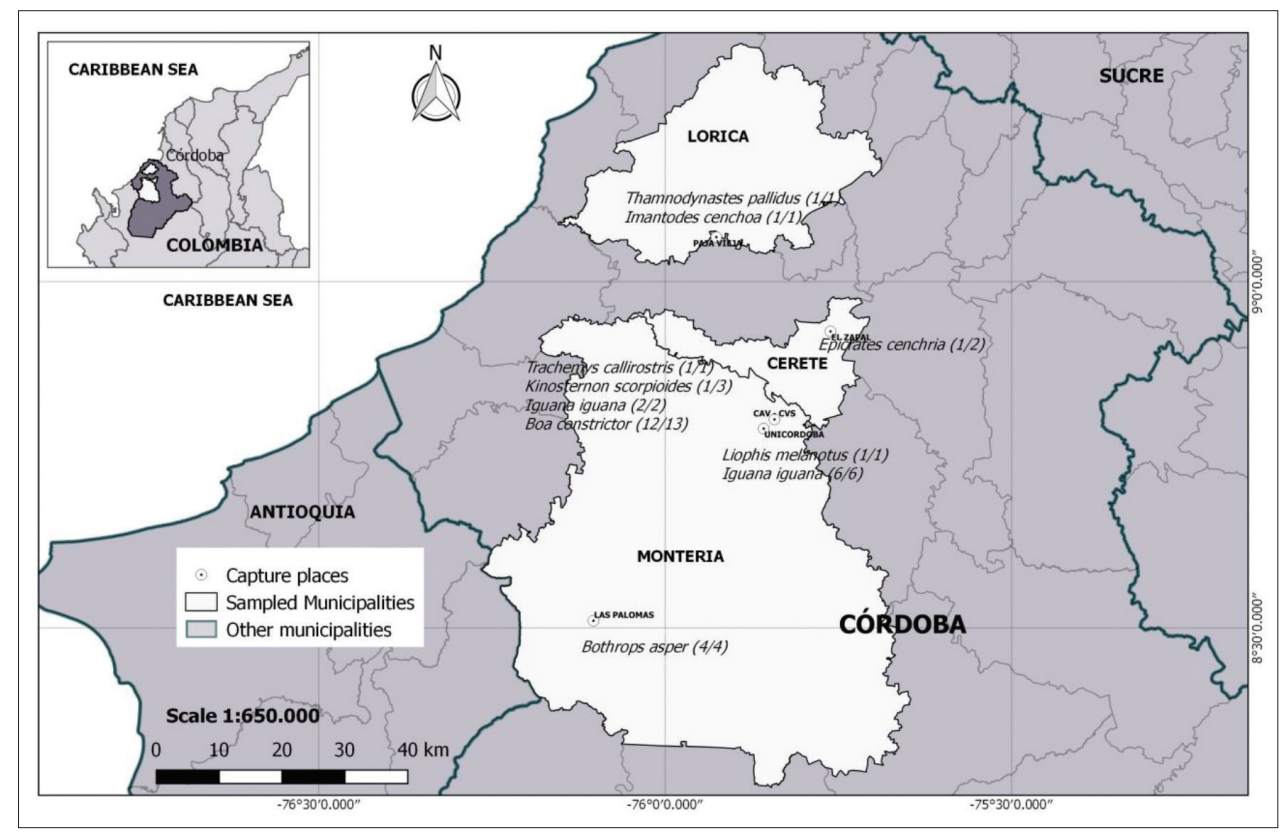

Figure-1: Area and sites of specimen collection, Cordoba, Colombia [Source: This map was designed by the authors of the manuscript and Misael Oviedo and Yulisa Velasquez executed the idea using QGIS (VERSION 3.14) software]. 


\section{Molecular detection of Rickettsia spp.}

The tick pools were placed in tubes containing $200 \mu \mathrm{l}$ PBS. DNA extraction was performed using the QIAamp Mini DNA kit (QIAGEN, CA, USA), according to the manufacturer's instructions. For the detection of Rickettsia spp., real-time polymerase chain reaction (RT-PCR) was performed using the primers CS-5: GAGAGAAAATTATATATCCAAATGTTGAT and CS-6AGGGTCTTCGTGCATTTCTT and ahydrolysis probe -FAM-CATTGTGCCATCCAGCCTACGGTBHQ-1 for the detection of a fragment of citrate synthase gene ( $g l t A, 147 \mathrm{bp}$ ) as described by Labruna et al. with some modifications [19]. Two negative controls were included in each test. DNA of Rickettsia amblyommatis was used as a positive control, and internal control of phage lambda genomic control DNA (TIB MOLBIOL, NJ USA) was also used in each amplification reaction. Next, the samples determined to be positive by RT-PCR were further analyzed by conventional PCR using two sets of primers, the CS-78 GCAAGTATCGGTGAGGATGTAAT and CS-323 GCT TCCTTAAAAT TCAATAAATCAGGAT for detecting a larger fragment of the gltA gene of $401 \mathrm{bp}$. For better identification of the rickettsia species, a fragment of $426 \mathrm{bp}$ of the 16 rRNA gene was also amplified with the primers fD1 AGAGTTTGATCCTGGCTCAG and Re16S. 452n AACGTCATTATCTTCCTTGC [19,20]. For each reaction, $5 \mu$ of molecular grade water was included as a negative control and $5 \mu \mathrm{l}$ of $R$. amblyommatis DNA was used as a positive control. The PCR products were visualized by electrophoresis on a $1.5 \%$ agarose gel. These products were purified for subsequent sequencing using a QuickLink ${ }^{\mathrm{TM}}$ gel extraction kit (Invitrogen) according to the manufacturer's instructions. The prevalence of infection caused by Rickettsia spp. in ticks was expressed as the minimum infection rate (MIR), which is the minimum detectable percentage of ticks infected by Rickettsia in a group. This was based on the fact that each PCR-positive group contained at least one infected tick [16].

\section{Phylogenetic analysis}

Sequencing was performed using the Sanger method. Subsequently, the obtained DNA partial sequences were aligned and compared with other sequences of Rickettsia available in GenBank. The identification of species was conducted by sequence homology using the MEGA X software (https://www. megasoftware.net/), in which multiple alignments of the sequences reported for the genus Rickettsia were made available in GenBank. For constructing the phylogenetic trees, the distances between homologous sequences were calculated using Kimura's two-parameter model. For each gene analyzed, a phylogenetic tree was constructed using the maximum likelihood method. The confidence values for the individual branches of the resulting tree were determined by bootstrap analysis with 1000 repetitions [21].

\section{Results}

\section{Identification of ticks}

From a total of 21 reptiles, 805 ticks of $A$. dissimile were identified (Figure-2). According to their development stage, 499 (61.9\%) were nymphs, 173 $(21.5 \%)$ were males, $96(11.9 \%)$ were females, and $37(4.6 \%)$ were larvae. Based on the host, $653(81 \%)$ ticks were collected from eight snakes (B. constrictor), and $68(8.4 \%)$ ticks were collected from one snake (E. maurus). The other hosts and ticks collected in this study and the sites of origin are described in Table- 1 .

\section{Molecular detection}

Of the 805 ticks sampled, 180 were used to set up 34 groups. The DNA from Rickettsia spp. was detected in 30/34 (88.23\%) groups of ticks analyzed by real-time PCR. Regarding the groups of ticks, according to reptile host species, we detected an infection prevalence range of 33-100\% (Table-2).

Through conventional PCR, the gltA gene (401 bp) and the $16 S r R N A$ gene were amplified in 18 (60\%) of the 30 positive pools by real-time PCR; six groups corresponded to the ticks of individuals of I. iguana, four pools were from B. asper, five pools were from B. constrictor, and one pool was from each of the following: E. melanotus, E. maurus, and I. cenchoa. The pools of ticks from the reptiles $T$. callirostris and $K$. scorpioides were not amplified in the conventional PCR assay.

\section{Phylogenetic analysis}

The amplified products of the gltA gene revealed nucleotide sequences identical to each other and with $100 \%$ similarity to those of Candidatus Rickettsia colombianensi (GenBank ${ }^{\circledR}$ : KF905456) and Rickettsia spp. clone Necocli 190 (JX519583) and $99 \%$ similarity to those of $R$. tamurae (AF394896), the closest validated species (Figure-3). The $16 \mathrm{~S}$ $r R N A$ gene nucleotide sequences demonstrated 100\% identity with Candidatus Rickettsia colombianensi (GenBank: KF691750) and 99\% identity with $R$. rhipicephali (GenBank: CP003342). Figure-4 shows the phylogenetic analysis of the sequences.

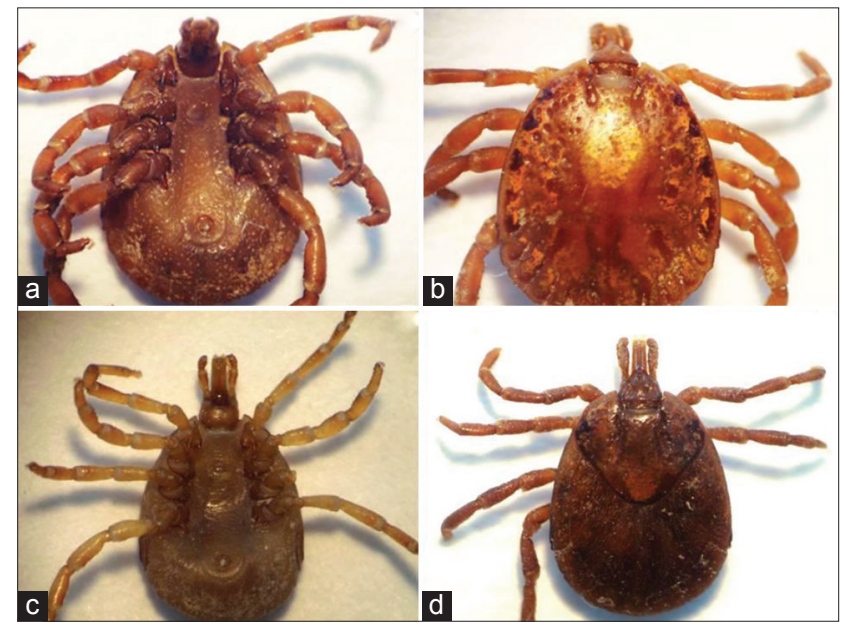

Figure-2: Adult specimen of Amblyomma dissimile: (a) Male frontal; (b) male dorsal; (c) frontal female; and (d) dorsal female view. 
Available at www.veterinaryworld.org/Vol.13/September-2020/5.pdf

Table-1: Hosts, number, and stage of development of ticks collected and pools analyzed by RT-PCR.

\begin{tabular}{|c|c|c|c|c|c|c|c|}
\hline \multicolumn{2}{|l|}{ Host species } & \multicolumn{5}{|c|}{ Collected ticks } & \multirow{2}{*}{$\begin{array}{c}\text { Pools of ticks } \\
\text { analyzed by } R T-P C R\end{array}$} \\
\hline Species & Origen & $\mathbf{F}$ & $\mathbf{M}$ & $\mathbf{N}$ & $\mathbf{L}$ & Total & \\
\hline Trachemys callirostris & CAV-CVS* (Montería) & 1 & - & - & - & 1 & $(1 \mathrm{~F})$ \\
\hline Kinosternon scorpioides & & 2 & 2 & - & - & 4 & $(2 \mathrm{M})(2 \mathrm{~F})$ \\
\hline Kinosternon scorpioides & & - & 3 & 4 & - & 7 & (3M) \\
\hline Boa constrictor & & 6 & 14 & - & - & 20 & $(14 M)(4 N)$ \\
\hline Boa constrictor & & - & - & 367 & - & 367 & $(7 N)$ \\
\hline Boa constrictor & & 10 & 32 & 52 & - & 94 & $(12 \mathrm{M})(5 \mathrm{~F})$ \\
\hline Boa constrictor & & 9 & 24 & - & - & 33 & $(6 \mathrm{M})(4 \mathrm{~F})$ \\
\hline Boa constrictor & & - & 3 & - & - & 3 & $(3 \mathrm{M})$ \\
\hline Boa constrictor & & 44 & 52 & - & - & 96 & $(7 F)(7 M)$ \\
\hline Boa constrictor & & 10 & 14 & 7 & - & 31 & $(7 F)(7 M)$ \\
\hline Boa constrictor & & 4 & 5 & - & - & 9 & $(5 \mathrm{M})$ \\
\hline Iguana iguana & & 2 & 4 & - & - & 6 & $(2 F)(4 M)$ \\
\hline Iguana iguana & Unicordoba (Montería) & - & - & - & 8 & 8 & $(8 \mathrm{~L})$ \\
\hline Iguana iguana & & 2 & 6 & - & 7 & 15 & $(2 F)(6 M)(7 L)$ \\
\hline Iguana iguana & & - & 4 & - & - & 4 & $(4 M)$ \\
\hline Iguana iguana & & - & 1 & - & - & 1 & $(1 \mathrm{M})$ \\
\hline Erythrolamprus melanotus & & - & - & - & 14 & 14 & $(14 L)$ \\
\hline Bothrops asper & Las Palomas (Montería) & 2 & 1 & 9 & 7 & 19 & $(2 F)(1 M)(9 N)(7 L)$ \\
\hline Thamnodynastes gambotensis & Paja Vieja (Lorica) & - & - & - & 1 & 1 & $(1 \mathrm{~L})$ \\
\hline Imantodes cenchoa & & - & - & 4 & - & 4 & $(4 N)$ \\
\hline Epicrates maurus & El Zapal (Cereté) & 4 & 8 & 56 & - & 68 & $(5 N)(7 N)$ \\
\hline Total & & 96 & 173 & 499 & 37 & 805 & $34(180)$ \\
\hline
\end{tabular}

*CAV-CVS=Centre for animal care of wildlife of Cordoba; UNICORDOBA (University of Córdoba). F=Females, M=Males, $\mathrm{N}=$ Nymphs, $\mathrm{L}=$ Larvae, $-=0$, RT-PCR $=$ Real-time polymerase chain reaction

Table-2: Host and percentage of infected groups with Rickettsia spp.

\begin{tabular}{llccc}
\hline $\begin{array}{l}\text { Number of } \\
\text { specimens }\end{array}$ & Host species & Collected ticks (\%) & $\begin{array}{c}\text { Analyzed pools by PCR/ } \\
\text { positive pools (\%) }\end{array}$ & $\begin{array}{c}\text { Minimum infection } \\
\text { rate* (\%) }\end{array}$ \\
\hline 1 & Trachemys callirostris & $1(0.12)$ & $1 / 1(100)$ & $1 / 1(100)$ \\
1 & Thamnodynastes gambotensis & $1(0.12)$ & $1 / 1(100)$ & $1 / 1(100)$ \\
1 & Imantodes cenchoa & $4(0.50)$ & $1 / 1(100)$ & $1 / 4(25)$ \\
1 & Erythrolamprus melanotus & $14(1.74)$ & $1 / 1(100)$ & $1 / 14(7)$ \\
1 & Bothrops asper & $19(2.36)$ & $4 / 4(100)$ & $4 / 19(21)$ \\
1 & Epicrates maurus & $68(8.45)$ & $2 / 1(50)$ & $1 / 12(8)$ \\
2 & Kinosternon scorpioides & $11(1.37)$ & $3 / 1(33)$ & $1 / 7(14)$ \\
5 & Iguana iguana & $34(4.22)$ & $8 / 8(100)$ & $8 / 34(23)$ \\
8 & Boa constrictor & $653(81.12)$ & $13 * * / 12(92)$ & $12 / 88(13)$ \\
21 & Total & $805(100)$ & $34 / 30(88)$ & $30 / 180(16)$ \\
\hline
\end{tabular}

*Minimum infection rate: Represents the minimum percentage of ticks infected by Rickettsia in a group, this is based on the fact that each positive PCR group contains at least one infected tick. $* * 88$ ticks were taken to make up the 13 groups. $\mathrm{PCR}=$ Polymerase chain reaction

\section{Discussion}

Candidatus Rickettsia colombianensi was detected in ticks collected from reptiles in Córdoba, which confirmed that it is a microorganism endemic to the area investigated in this study and possibly endemic throughout Colombia where A. dissimile is found. A. dissimile was the only tick species found in reptiles analyzed in this study. Similar results have been reported in the previous research conducted in the same geographic area on the green iguana (I. iguana) [16] and in other departments (La Guajira, Cesar, and Magdalena), where $A$. dissimile was the only ectoparasite found on the reptiles [22]. In another study, $A$. dissimile was the only tick species found in the toads Rhinella humboldti and Rhinella horribilis in the Magdalena Department [23]. A. dissimile has been described as one of the major ectoparasites of those reptiles kept in captivity and subjected to illegal wildlife trafficking in the Department of Córdoba [24,25].

A. dissimile has also been reported in other countries, parasitizing iguanas of the species Ctenosaura bakeri and I. iguana in Honduras [26] and the snake B. constrictor in Costa Rica [27]. This is probably because $A$. dissimile is the most widely distributed tick species in reptiles and amphibians in Central and South America [28]. In contrast to our results, studies conducted in Mexico reported that reptiles were infested either individually or in groups with Amblyomma mixtum, Amblyomma rotundatum, Amblyomma sabanerae, and Amblyomma scutatum but not with A. dissimile [29]. However, other researchers in Mexico have reported $A$. dissimile infestations on reptiles [30].

To the best of our knowledge, the present study is the first report in Colombia regarding 


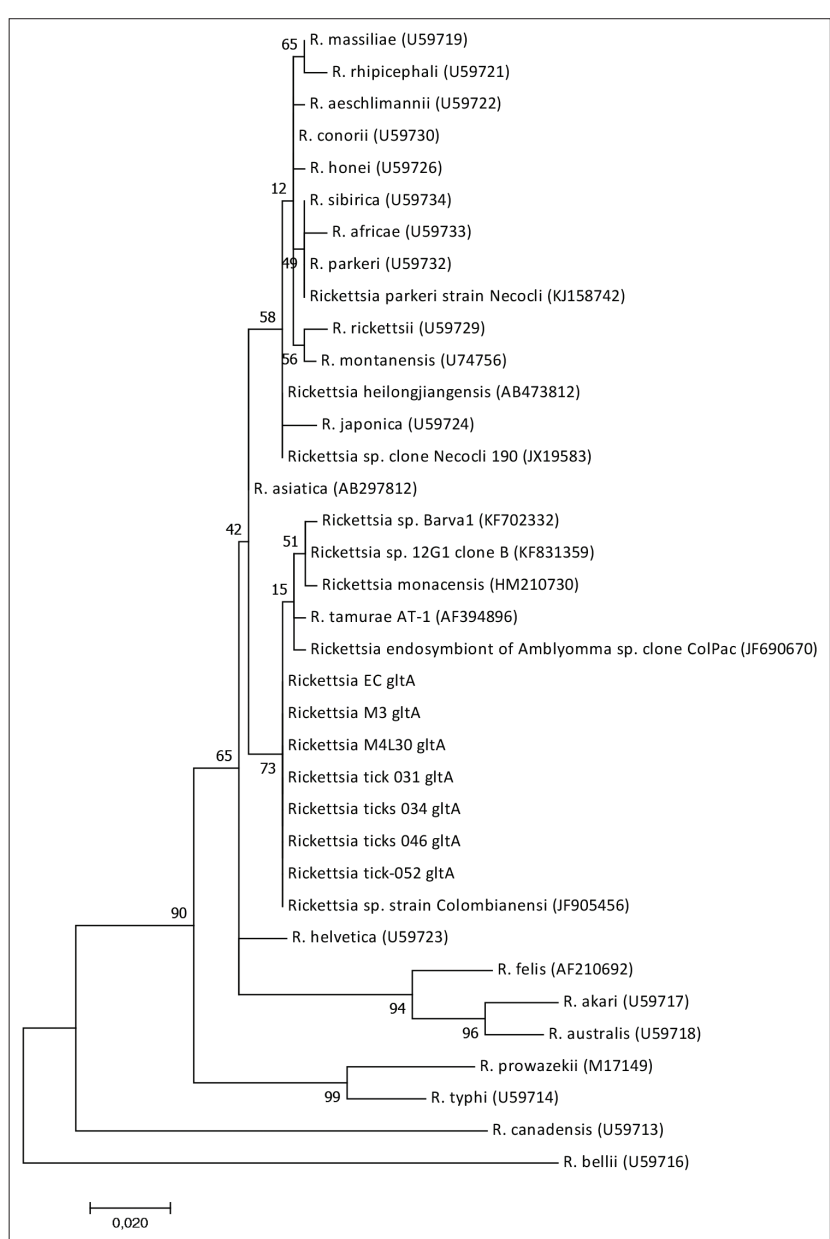

Figure-3: Phylogenetic analysis of the sequences of a 350-bp fragment of the gltA gene from Rickettsia colombianensi, amplified from Amblyomma dissimile. The tree was built by the maximum likelihood method. The branch supports (Bootstrap) of the evolutionary analysis were made with 1000 replicas in the MEGA $X$ program. The access number of each species of Rickettsia is shown in parentheses.

Candidatus Rickettsia colombianensi in A. dissimile collected from reptiles of the species $T$. callirostris, T. gambotensis, I. cenchoa, E. melanotus, B. asper, $E$. maurus, and $K$. scorpioides, with high frequency of detection, between $33 \%$ and $100 \%$ within the tested groups. In our study, the MIR of Candidatus Rickettsia colombianensi in $A$. dissimile ticks was $16 \%$, assuming one positive tick per group. This result is similar to the $15 \%$ prevalence in A. dissimile in the Departments of Magdalena, Cesar, and La Guajira, Colombia [22]. However, in the previous reports of Candidatus Rickettsia colombianensi in A. dissimile in Córdoba collected from I. iguana, the MIR was 29\% [16]. Cotes-Perdomo reported Candidatus Rickettsia colombianensi in A. dissimile collected from toads (Rhinella horribilis and R. humboldti) at frequencies of 55\% (5/9 adults), $57 \%$ (24/41 groups of nymphs), and $88 \%$ (28/32 groups of larvae) [23].

Candidatus Rickettsia colombianensi has also been reported in A. dissimile on the iguanas C. bakeri and I. iguana and in larvae of Amblyomma spp.

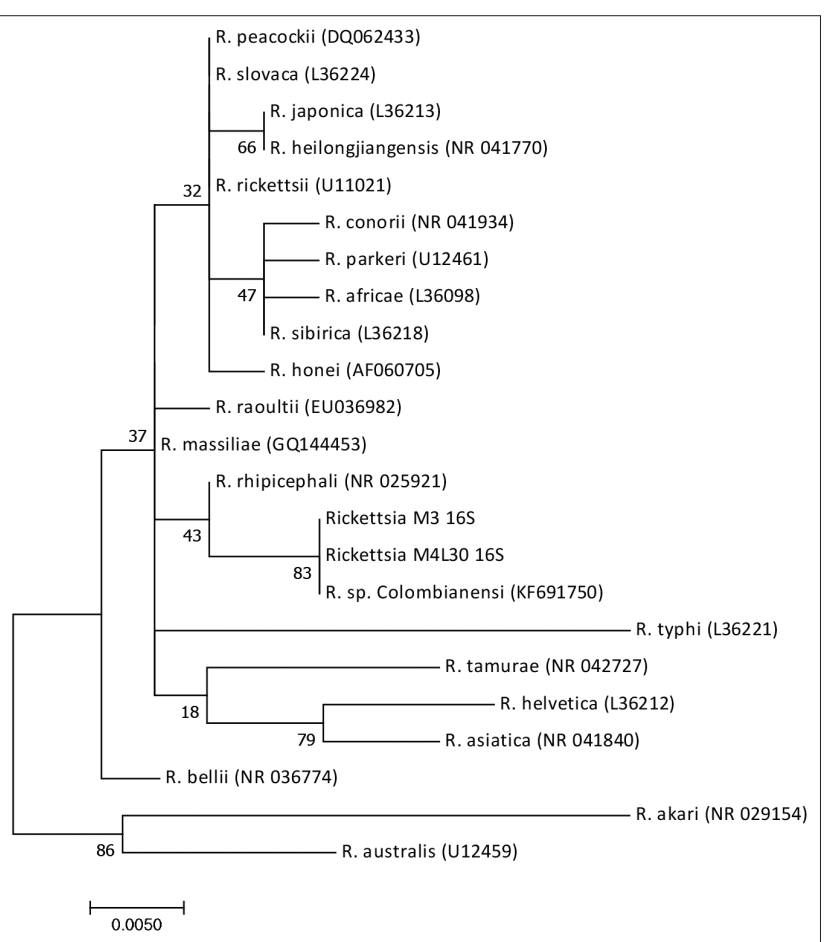

Figure-4: Phylogenetic analysis of the sequences of a $350 \mathrm{bp}$ fragment of the 16S rRNA gene of the Candidatus Rickettsia colombianensi, amplified from Amblyomma dissimile. The tree was built by the maximum likelihood method. The branch supports (Bootstrap) of the evolutionary analysis were made with 1000 replicas in the MEGA X program. The access number of each species of Rickettsia is shown in parentheses.

on the bird species Geothlypis formosa in Honduras; However, Novakova et al. [26] in the analysis of the sequence of this rickettsia it showed that it had differences in the genetic sequence $(0.4 \%)$ with respect to Candidatus Rickettsia colombianensi detected in Colombia, for this reason, it was named Candidatus Rickettsia colombianensi genotype Utila. In Brazil, Rickettsia that were $100 \%$ identical to Candidatus Rickettsia colombianensi were detected in a group of ten larval $A$. dissimile collected from toads (Rhinella marina) [31].

Ticks of reptiles and amphibians could play an essential role in the transmission of new rickettsial species, with some potential pathogenicity. Rickettsia spp. RDa420 is a part of the spotted fever group, described among the ticks Amblyomma helvolum and Amblyomma varanense collected from the snakes Python molurus bivittatus, Xenochrophis piscator, Ptyas korros, and Ophiophagus hannah in Thailand [32]. In Malaysia [33], among the same ticks (A. helvolum and $A$. varanense) collected from captured snakes, two new Rickettsiae, Candidatus Rickettsia sepangensis, similar to Rickettsia tamurae, and Candidatus Rickettsia johorensis, which is very close to Rickettsia raoultii. Rickettsia bellii has been described from $A$. rotundatum ticks collected from turtles (Chelonoidis carbonaria) that are illegally traded between Israel and the United States [34]. R. bellii has also been reported in A. rotundatum collected from 
amphibians (Rhinella jimi) from the arid regions of Brazil [35], and in Colombia, it has been described from a group of $A$. dissimile larvae collected from the lizard Basiliscus basiliscus and the toad R. horribilis in the Department of Magdalena, Colombia [22,23].

The presence of ticks belonging to the genus Amblyomma in illegally trafficked reptiles has become a public health concern in the United States and some countries of the European continent, which is because ticks can develop breeding colonies and establish themselves as endemic, affecting the populations of native reptiles and even domestic livestock $[11,36]$.

\section{Conclusion}

The potential danger of illegal trade of reptiles with respect to the spread of diseases has already been described. The finding of Rickettsia from the spotted fever group in illegally trafficked reptile ticks would pose a health risk. It is known that these types of Rickettsiae are potentially pathogenic for humans, and the trade of live reptiles could be a mechanism responsible for their introduction into countries where they are currently not detected. Our findings suggest that it is important to establish sanitary and veterinary measures to control the trade and holding of captive reptiles and to prevent the potential risk of transmission of Rickettsia spp. to humans.

\section{Authors' Contributions}

$\mathrm{JM}, \mathrm{LV}$, and SaM conceived and designed the experiments; JM, LV, SB, and VC collected, classified ticks, and performed the experiments; JM, LV, $\mathrm{VC}, \mathrm{SM}, \mathrm{SaM}$, and JR analyzed the data, wrote, and revised the manuscript. All authors read and approved the final manuscript.

\section{Acknowledgments}

Thanks to Dr. James Mills, for the critics and style grammar corrections, to Misael Oviedo and Yulisa Velasquez for the design of the graphics. To CAV-CVS: (Centro de Atención y Valoración de la fauna Silvestre - Corporación de los Valles del Sinú y San Jorge) for authorization to collect samples. This work was supported by the COLCIENCIAS call 5622012 project bank $\mathrm{I}+\mathrm{D}+\mathrm{I}$ (Investigation + Developed and Innovation), from the National Biotechnology Program and the National Program for the Research and Development of Veterinary Products. Pharmaceutical Nanotechnology and Innovation Strategy, Colombia (code 127556238833).

\section{Competing Interests}

The authors declare that they have no competing interests.

\section{Publisher's Note}

Veterinary World remains neutral with regard to jurisdictional claims in published map and institutional affiliation.

\section{References}

1. Warwick, C. and Corning, S. (2013) Managing patients for zoonotic disease in hospitals. JRSM Short Rep., 4(8): 2-9.

2. Ghosh, H. and Misra, K. (2012) Scanning electron microscope study of a snake tick, Amblyomma gervaisi (Acari: Ixodidae). J. Parasit. Dis., 36(2): 239-250.

3. Brites-Neto, J., Roncato, K.M. and Fernandes, T. (2015) Tick-borne infections in human and animal populations worldwide. Vet. World, 8(3): 301-315.

4. Eisen, R., Kugeler, K., Eisen, L., Beard, C. and Paddock, C. (2017) Tick-borne zoonoses in the United States: Persistent and emerging threats to human health. ILAR J., 58(3): 319-335.

5. World Health Organization. (2020) Vector-borne diseases. Accessed August 20, 2020, from: https://www.who. $\mathrm{int} /$ news-room/fact-sheets/detail/vector-borne-diseases. Retrieved on 24-08-2020.

6. De Sousa, R., De Carvalho, I., Santos, A., Bernardes, C., Milhano, N., Jesus, J., Menezes, D. and Nuncio, M. (2012) Role of the lizard Teira dugesii as a potential host for Ixodes ricinus tick-borne pathogens. Appl. Environ. Microbiol., 78(10): 3767-3769.

7. Kaenkan, W., Nooma, W., Chelong, I., Baimai, V., Trinachartvanit, W. and Ahantarig, A. (2020) Reptileassociated Borrelia spp. in amblyomma ticks, Thailand. Ticks Tick Borne. Dis., 11(1): 101315.

8. Sánchez-Montes, S., Isaak-Delgado, A.B., Guzmán-Cornejo,C., Rendón-Franco, E., Muñoz-García, C.I., Bermúdez, S., Morales-Diaz, J., Cruz-Romero, A., Romero-Salas, D., Dzul-Rosado, K., Lugo-Caballero, C., Colunga-Salas, P. and Becker, I. (2019) Rickettsia species in ticks that parasitize amphibians and reptiles: Novel report from mexico and review of the worldwide record. Ticks Tick Borne Dis., 10(5): 987-994.

9. Rodríguez, N. and García, O. (2008) Comercio de fauna silvestre en colombia. Rev. Fac. Nac. Agron. Medellin, 61(2): 4618-4645.

10. Burridge, M.J., Simmons, L.A. and Allan, S.A. (2000) Introduction of potential heartwater vectors and other exotic ticks into Florida on imported reptiles. J. Parasitol., 86(4): 700-704.

11. Mihalca, A.D. (2015) Ticks imported to Europe with exotic reptiles. Vet. Parasitol., 213(1-2): 67-71.

12. Nowak, M. (2010) The international trade in reptiles (Reptilia): The cause of the transfer of exotic ticks (Acari: Ixodida) to Poland. Vet. Parasitol., 169(3): 373-381.

13. Shpynov, S., Fournier, P., Pozdnichenko, N., Gumenuk, A. and Skiba, A. (2018) New approaches in the systematics of rickettsiae. New Microbes New Infect., 23: 93-102.

14. Ekner, A., Dudek, K., Sajkowska, Z., Majláthová, V., Majláth, I. and Tryjanowski, P. (2011) Anaplasmataceae and Borrelia burgdorferi sensu lato in the sand lizard Lacerta agilis and co-infection of these bacteria in hosted Ixodes ricinus ticks. Parasit. Vectors, 4(1): 182.

15. Miranda, J., Mattar, S., Puerta-González, A., Muskus, C. and Oteo, J.A. (2019) Genome sequence of "Candidatus Rickettsia colombianensi," a novel tick-associated bacterium distributed in Colombia. Microbiol. Resour. Announc., 8(14): e01433-18.

16. Miranda, J., Portillo, A., Oteo, J.A. and Mattar, S. (2012) Rickettsia sp. strain colombianensi (Rickettsiales: Rickettsiaceae): A new proposed Rickettsia detected in Amblyomma dissimile (Acari: Ixodidae) from iguanas and free-living larvae ticks from vegetation. J. Med. Entomol., 49(4): 960-965.

17. Barros-Battesti, D.M., Arzua, M. and Bechara, G.H. (2006) Carrapatos de Importância Médico-Veterinária Da Região Neotropical: Um Guia Ilustrado Para Identificação de Espécies. ICTTD-3/Instituto Butantan, Butantan.

18. Martins, T.F., Onofrio, V.C., Barros-Battesti, D.M. and Labruna, M.B. (2010) Nymphs of the genus Amblyomma (Acari: Ixodidae) of Brazil: Descriptions, redescriptions, 
and identification key. Ticks Tick Borne Dis., 1(2): 75-99.

19. Labruna, M.B., Whitworth, T., Horta, M.C., Bouyer, D.H., McBride, J.W., Pinter, A., Popov, V., Gennari, S.M. and Walker, D.H. (2004) Rickettsia species infecting Amblyomma cooperi ticks from an area in the state of Sao Paulo, Brazil, where Brazilian spotted fever is endemic. $J$. Clin. Microbiol., 42(1): 90-98.

20. Miranda, J. and Mattar, S. (2014) Molecular detection of Rickettsia bellii and Rickettsia sp. strain colombianensi in ticks from Cordoba, Colombia. Ticks Tick Borne Dis., 5(2): 208-212.

21. Kumar, S., Stecher, G., Li, M., Knyaz, C. and Tamura, K. (2018) MEGA X: Molecular evolutionary genetics analysis across computing platforms. Mol. Biol. Evol., 35(6): $1547-1549$.

22. Santodomingo, A., Cotes-Perdomo, A., Foley, J. and Castro, L.R. (2018) rickettsial infection in ticks (Acari: Ixodidae) from reptiles in the Colombian Caribbean. Ticks Tick Borne Dis., 9(3): 623-628.

23. Cotes-Perdomo, A., Santodomingo, A. and Castro, L.R. (2018) Hemogregarine and rickettsial infection in ticks of toads from Northeastern Colombia. Int. J. Parasitol. Parasites Wildl., 7(2): 237-242.

24. Carrascal, J., Oviedo, T., Monsalve, S. and Torres, A. (2009) Amblyomma dissimile (Acari: Ixodidae) parasite of Boa constrictor in Colômbia. Rev. MVZ Córdoba, 14(2): 1745-1749.

25. Krebber, H., Mestra, A., Herreral, Y. and Causil, L. (2017) Amblyomma dissimile in Boa constrictor in captivity at the wildlife attention and valuation center in Montería (Córdoba, Colombia). Rev. Med. Vet. (Bogota)., 35: 29-34.

26. Novakova, M., Literak, I., Chevez, L., Martins, T.F., Ogrzewalska, M. and Labruna, M.B. (2015) Rickettsial infections in ticks from reptiles, birds and humans in Honduras. Ticks Tick Borne Dis., 6(6): 737-742.

27. Troyo, A., Moreira-Soto, R.D., Calderon-Arguedas, Ó., Mata-Somarribas, C., Ortiz-Tello, J., Barbieri, A.R.M., Avendaño, A., Vargas-Castro, L.E., Labruna, M.B. and Hun, L. (2016) Detection of rickettsiae in fleas and ticks from areas of Costa Rica with history of spotted fever group rickettsioses. Ticks Tick. Borne Dis., 7(6): 1128-1134.

28. Freitas, L.H.T., Faccini, J.L.H., Daemon, E., Prata, M.C.A and Barros-Battesti, D.M. (2004) Experimental infestation with the immatures of Amblyomma dissimile Koch, 1844 (Acari: Ixodidae) on Tropidurus torquatus (Lacertilia: Iguanidae) and Oryctolagus cuniculus. Arq. Bras. Med. Vet. Zootec., 56(1): 126-129.

29. Rodríguez-Vivas, R.I., Apanaskevich, D.A., OjedaChi, M.M., Trinidad-Martínez, I., Reyes-Novelo, E., Esteve-Gassent, M.D. and de León, A.A. (2016) Ticks collected from humans, domestic animals, and wildlife in Yucatan, Mexico. Vet. Parasitol., 215: 106-113.

30. Charruau, P., Pérez-Flores, J., Cedeño-Vázquez, J.R., Gonzalez-Solis, D., González-Desales, G.A., MonroyVilchis, O. and Desales-Lara, M.A. (2016) Occurrence of Amblyomma dissimile on wild crocodylians in Southern Mexico. Dis. Aquat. Organ., 121(2): 167-171.

31. Luz, H., Silva-Santos, E., Costa-Campos, C., Acosta, I., Martins, T.F., Muñoz-Leal, S., McIntosh, D., Faccini, J. and Labruna, M.B. (2018) Detection of Rickettsia spp. in ticks parasitizing toads (Rhinella marina) in the Northern Brazilian Amazon. Exp. Appl. Acarol., 75(3): 309-318.

32. Sumrandee, C., Hirunkanokpun, S., Doornbos, K., Kitthawee, S., Baimai, V., Grubhoffer, L., Trinachartvanit, W. and Ahantarig, A. (2014) Molecular detection of Rickettsia species in Amblyomma ticks collected from snakes in Thailand. Ticks Tick Borne Dis., 5(6): 632-640.

33. Kho, K.L., Koh, F.X. and Tay, S.T. (2015) Molecular evidence of potential novel spotted fever group rickettsiae, Anaplasma and Ehrlichia species in Amblyomma ticks parasitizing wild snakes. Parasit. Vectors, 8(1): 112.

34. Erster, O., Roth, A., Avni, Z., King, R. and Shkap, V. (2015) Molecular detection of Rickettsia bellii in Amblyomma rotundatum from imported red-footed tortoise (Chelonoides carbonaria). Ticks Tick Borne Dis., 6(4): 473-477.

35. Horta, M.C., Saraiva, D.G., Oliveira, G.M.B., Martins, T.F. and Labruna, M.B. (2015) Rickettsia bellii in Amblyomma rotundatum ticks parasitizing Rhinella jimi from Northeastern Brazil. Microbes Infect., 17(11-12): 856-858.

36. Burridge, M.J. and Simmons, L.A. (2003) Exotic ticks introduced into the United States on imported reptiles from 1962 to 2001 and their potential roles in international dissemination of diseases. Vet. Parasitol., 113(3-4): 289-320. 